\title{
PERAN PEMERINTAH DESA DALAM PENGEMBANGAN BADAN USAHA MILIK DESA (BUMDes)
}

\author{
Ferdi Harobu Ubi Laru Agung Suprojo \\ Program Studi Adminitrasi Publik, Fakultas Ilmu Sosial dan Politik, \\ Universitas Tribhuwana Tunggadewi \\ Email: ferdilaru@yahoo.com
}

\begin{abstract}
Abstrak : Tujuan dari penelitian ini adalah untuk mendeskripsikan peran Pemerintah Desa Tlekung dalam pengembangan Badan Usaha Milik Desa (BUMDes), serta mengidentifikasi faktor-faktor yang berperan dalam pelaksanaan peran yang dilakukan oleh Pemerintah Desa Tlekung. Penelitian yang dilakukan dengan pendekatan kualitatif, dengan menggunakan teknik pengumpulan data triangulasi dan teknik analisis interaktif Miles and Huberman. Hasil dari penelitian diketahui bahwa terdapat lima peran yang telah dilakukan oleh Pemerintah Desa Tlekung. Dalam menjalankan peranannya tersebut terdapat Faktor pendukung yaitu tersedianya sarana prasana, adanya kebijakan khususmengenai pengurus, adanya pembinaan dan pengawasan. Sedangkan untuk faktor penghambat yang dihadapi adalah minimnya kesadaran masyarakat dalam melakukan pengembalian piutang, dan minimnya kemampuan pengurus dalam hal pembuatan laporan keuangan.
\end{abstract}

Kata kunci: Peran, Pemerintah Desa, Badan Usaha Milik Desa

\begin{abstract}
The purpose of this study is to describe the role of the Tlekung Village Government in the development of Village-Owned Enterprises (BUMDes), and identify the factors that play a role in the implementation of the role carried out by the Tlekung Village Government. This study uses a qualitative approach, using triangulation data collection techniques and Miles and Huberman's interactive analysis techniques. The results showed that there were five roles that had been carried out by the Tlekung Village Government. In carrying out this role, there are supporting factors, namely the availability of infrastructure, the existence of special policies regarding management, guidance and supervision. The inhibiting factors were the lack of public awareness in returning receivables, and the lack of the board's ability to make financial reports.
\end{abstract}

Keywords: The Role, Village Government, Village-Owned Enterprises

\section{PENDAHULUAN}

Undang - Undang Negara Republik Indonesia Nomor 6 tahun 2014 Tentang Desa, menjelaskan Desa merupakan organisasi pemerintahan terkecil, terbawah, terdepan dan terdekat dengan masyarakat. Sehingga Larasati dan Muhammad Okto (2017) menjelaskan bahwa kemajuan sebuah negara tergantung oleh desa, karena mustahil sebuah negara bisa maju apabila provinsinya tidak maju, begitu pula tidak ada provinsi yang maju tanpa kabupaten/kota yang maju, dan tidak pula maju sebuah kabupaten/kota yang maju mustahil tanpa adanya desa/kelurahan yang maju pula. Ini berarti bahwa basis kemajuan sebuah Negara ditentukan oleh kemajuan desa. Kemajuan sebuah desa ditentukan oleh pelaksanaan pembangunan. Dimana sebuah Pembangunan Desa memiliki tujuan meningkatkan kesejahteraan masyarakat dan kualitas hidup masyarakat serta penanggulangan kemiskinan melalui pemenuhan kebutuhan dasar, pembangunan sarana dan prasarana Desa, pengembangan potensi ekonomi lokal, serta pemanfaatan sumber daya alam dan lingkungan secara berkelanjutan. Tentunya dalam tataran pembangunan desa, tidak terlepas dari peran pemerintah desa dalam mengelola dan mengembangkan BUMDes, karena hal ini berkaitan dengan kondisi ekonomi masyarakat, 
pertumbuhan dan perkembangan Desa sangat berpengaruh pada kesejahteraan masyarakat. BUMDes diharapkan menjadi sebuah alternatif untuk memberdayakan masyarakat desa. Sesuai berdasarkan Undang-Undang tersebut peran pemerintah dalam rangka mengakomodasi potensi desa dan pemenuhan kebutuhan warga desa dengan memberikan dukungan besar melalui badan usaha yang mampu mengembangkan dan menggerakkan perekonomian lokal.

Dalam Undang - Undang Desa pasal sembilan puluh diatur secara tersurat bahwa semua tataran Pemerintah di Indonesia baik itu dari Pemerintah Daerah Provinsi, Pemerintah Daerah Kabupaten/Kota, dan Pemerintah Desa memiliki peranan untuk mendorong perkembangan Badan Usaha Milik Desa (BUMDes) dengan berbagai cara yaitu sebagaimana berikut ini yaitu memberikan hibah dan/atau akses permodalan; melakukan pendampingan secara teknis dan akses ke pasar; serta memprioritaskan BUMDes dalam pengelolaan sumber daya alam di Desa. Fenomena BUMDes di Jawa Timur hampir setiap Kabupaten maupun Kota mempunyai proyek pengembangan BUMDes. Pendirian BUMDes sendiri disesuaikan dengan karakteristik lokalitas dan kapasitas ekonomi desa yang ada, misalnya pengelolaan pasar desa, wisata desa, kegiatan simpan-pinjam, pengembangan kerajinan masyarakat dan lain sebagainya. Upaya mewujudkan konsep pendirian BUMDes, dirintis dengan jalan mengoptimalkan kapasitas dan kegiatan ekonomi yang sudah berjalan dan dikelola desa. Fokus penelitian yang dilakukan oleh peneliti mengambil lokasi penelitian di salah satu desa di Kota Batu yang telah memilih serta yakin untuk mengelola BUMDes secara mantap melalui kegiatan simpan pinjam yaitu Desa Tlekung Kecamatan Junrejo Kota Batu yang mendirikan Unit Pengelola Keuangan (UPK) Setya sebagai penyalur pinjaman dan penampungan tabungan masyarakat sekitar. Sehingga dengan adanya BUMDes di tengah perekonomian masyarakat desa diharapkan menjadi sebuah solusi alternatif untuk melindungi dan memberdayakan masyarakat desa.

Tujuan dari penelitian ini adalah untuk mengetahui peranan pemerintah desa dalam pengembangan Badan Usaha Milik Desa (BUMDes) dan mengidentifikasi faktor-faktor yang mempengaruhi peranan pemerintah desa dalam pengembangan Badan Usaha Milik Desa (BUMDes) pada Unit Pengelola Keuangan (UPK) Setya di Desa Tlekung Kecamatan Junrejo Kota Batu. Dari dua tujuan penelitian tersebut, maka dalam penelitian ini menggunakan teori yang berhubungan dengan peranan Pemerintah Desa. Peranan disini merupakan bertindak atau perangkat tingkah laku yang diharapkan dimiliki oleh orang yang berkedudukan di masyarakat (Harahap, dkk, 2007: 854). Menurut penjelasan Alam (2009), konsep peran semula dipinjam dari kalangan yang memiliki hubungan erat dengan drama atau teater yang hidup subur pada zaman yunani kuno atau romawi. Peran berarti karakter yang disandang atau dibawakan oleh seorang actor dalam sebuah pentas dengan lakon tertentu. Kedua, pengertian peran menurut ilmu sosial. Peran dalam ilmu sosial berarti suatu fungsi yang dibawakan seseorang ketika menduduki jabatan tertentu, seseorang dapat memainkan fungsinya karena posisi yang didudukinya tersebut Peran memberi makna dalam status, kedudukan dan masyarakat, dapat dijelaskan melalui beberapa cara, yaitu pertama penjelasan historis. Menurut Soekanto dalam Larasati dan Ya'taufiq Kurrahman (2019) dijelaskan pengertian dari sebuah peran adalah "Proses dinamis kedudukan (status). Jadi apabila seseorang melaksanakan hak dan kewajiban sesuai dengan kedudukannya, berarti dia menjalankan suatu peranan.

Dalam menjalankan perannya, Pemerintah Desa akan dihadapkan dengan beberapa faktor-faktor yang mempengaruhi dalam pembangunan berbasis Pemberdayaan Masyarakat yaitu sebagaimana berikut : Keadaan sumber daya alam (SDA), Kondisi sumber daya manusia (SDM), kemapanan kelembagaan untuk pembangunan, Sarana dan prasarana untuk pembangunan, Kebijakan pembangunan, Organisasi dan administrasi pemberdayaan masyarakat (Mardikanto dan Soebianto dalam Larasati dan Ya'taufiq Kurrahman, 2019) 
JISIP: Jurnal Ilmu Sosial dan IlmuPolitik

ISSN. 2442-6962

Vol. 8 No. 4 (2019)

\section{METODE PENELITIAN}

Peneliti menggunakan pendekatan penelitian kualitatif dengan perumusan masalah deskriptif, hal ini dilakukan dengan alasan supaya mendapatkan data yang holistik dalam mengetahui peran Pemerintah Desa Tlekung dalam mengembangkan Badan Usaha Milik Desa (BUMDes). Sehingga sumber data dalam penelitian ini adalah sumber data utama berasal dari hasil wawancara dengan beberapa informan yang ditetapkan mengunakan purposive sampling, observasi langsung yang dilakukan peneliti ketika penelitian dan sumber data tambahan berupa laporan-laporan serta dokumen yang ada di kantor desa Tlekung dan BUMDes. Teknik triangulasi dilakukan peneliti dalam mengumpulkan data di lapangan, dan peneliti menggunakan analisis interaktif Miles dan Huberman dalam menganalisis data yang sudah ada.

\section{HASIL DAN PEMBAHASAN}

\section{Peran Pemerintah Desa Dalam Pengembangan BUMDes Unit Pengelola Keuangan (UPK) Setya Di Desa Tlekung Kecamatan Junrejo Kota Batu)"}

Pendirian BUMDes untuk melaksanakan program pembangunan Desa dan pemberdayaan BUMDes. Tujuan awal pembentukan Badan Usaha Milik Desa (BUMDes) untuk mendorong atau menampung seluruh kegiatan peningkatan pendapatan masyarakat, baik yang berkembang menurut adat istiadat dan budaya setempat, maupun kegiatan perekonomian yang diserahkan untuk di kelola oleh masyarakat melalui program atau proyek Pemerintah dan Pemerintah Daerah. Sebagai sebuah usaha desa, pembentukan BUMDes diharapkan mampu memaksimalkan potensi masyarakat desa dari aspek ekonomi, sumber daya alam, dan sumber daya manusianya.

Secara spesifik, pendirian BUMDes Unit Pengelola Keuangan (UPK) Setya untuk menyerap tenaga kerja desa, meningkatkan kreativitas, dan membuka peluang usaha ekonomi produktif masyarakat yang meliliki modal usaha kurang. Sasaran pemberdayaan ekonomi masyarakat desa melalui BUMDes bertujuan untuk melayani masyarakat desa dalam mengembangkan usaha produktif. Tujuan lainnya adalah untuk menyediakan media beragam usaha dalam menunjang perekonomian masyarakat desa sesuai dengan potensi desa dan kebutuhan masyarakat. Oleh karena itu diperlukan intervensi Pemerintah desa sebagai unsur penyelenggaraan, perumus dan pelaksanaan kebijakan pemerintah desa. memberi fasilitas dan sebagai medioator bagi masyarakat. Berikut adalah Peran Pemerintah Desa Tlekung dalam pengembangan BUMDes UPK Setya sebagai berikut:

1. Sebagai fasilitator, Pemerintah Desa Tlekung mendukung dan membantu memberikan fasilitas kepada BUMDes UPK Setya. Fasilitator disini memiliki artian mengembangkan pembentukan BUMDes dan mendorong supaya BUMDes mampu menjalankan funginya sebagai penyangga ekonomi masyarakat desa. Karena diharapkan UPK Setya mampu memberikan perubahan terhadap taraf hidup warga desa (masyarakat) sehingga berimplikasi terhadap adanya peningkatan Pendapatan Asli Desa (PAD). Sebagai fasilitator, Pemerintah Desa mengeluarkan kebijakan tentang prasyarat menjadi pengurus UPK Setya, supaya UPK Setya dipegang dan dikelola dengan baik dan di tnagan yang benar. Selain itu, Pemerintah Desa Tlekung berupaya untuk melakukan peningkatan kapasitas pengurus UPK Desa Tlekung dengan berbagai macam pelatihan dan workshop kepada pengurus. Selain memberikan pelatihan dan workshop, pemerintah desa juga memberikan motivasi sehingga pengurus lebih semangat dan lebih profesional.

2. Pemerintah Desa Tlekung juga memberikan asistensi (melakukan pendampingan), mentoring dan coaching terhadap kinerja Pengurus BUMDes terhadap proses-proses pengelolaan usaha dan manajemen keuangan.

3. Pemerintah Desa Tlekung mendorong dan memfasilitasi proses refleksi dan persiapan pada setiap kegiatan yang akan dilakukan oleh UPK Setya. Penganggaran melalui Dana Hibah juga 
diperuntukkan sebagai tambahan modal. Unit Pengelola Keuangan (UPK) Setya sebagai lembaga keuangan yang khusus didirikan untuk memberikan jasa pengembangan usaha dan pemberdayaan masyarakat, baik melalui pinjaman atau pembiayaan dalam usaha skala mikro kepada anggota dan masyarakat, pengelolaan simpanan, maupun pemberian jasa konsultasi pengembangan usaha yang tidak semata-mata mencari keuntungan.

4. Pemerintah Desa Tlekung melakukan sosialisasi terhadap masyarakat mengenai keberadaan dan manfaat adanya BUMDes UPK Setya

5. Pemerintah Desa Tlekung mendorong BUMDes UPK Setya untuk bekerjasama dengan pihak ketiga dalam pengembangan berbagai usaha yang dilakukan oleh BUMDes, termasuk dalam pengelolaan aset, serta penganekaragaman usaha yang dimiliki

\section{Faktor-Faktor Yang Mempengaruhi Peran Pemerintah Desa dalam Pengembangan BUMDes Unit Pengelola Keuangan (UPK) Setya}

Faktor - faktor yang mempengaruhi peran pemerintah ini di kelompokkan menjadi Faktor Pendukung dan Faktor Penghambat. Berdasarkan hasil penelitian yang telah dilaksanakan, terdapat beberapa faktor pendukung dalam pengembangan BUMDes Unit Pengelola Keuangan (UPK) Setya yaitu yang pertama, tersedianya sarana prasana penunjang dalam pengelolaan yang cukup baik. Faktor pendukung kedua, Adanya kebijakan mengenai persyaratan untuk menjadi kepengurusan adalah yang memiliki pengalaman dan kemampuan. Dengan adanya kebjakan persyaratan kepengurusan, diharapkan BUMDes ditangani oleh orang-orang profesional, sehingga BUMDes yang ada semakin maju dan menganut prinsip transparansi, akuntabel, partisipatif, berkelanjutan serta akseptabel; dengan begitu BUMDes ang ada bisa melayani kebutuhan masyarakat dengan baik dan adil. Selain itu, faktor pendukung ketiga, Adanya pembinaan manajemen secara rutin dan mendapat pengawasan baik secara internal maupun eksternal. Faktor pendukung keempat yaitu adanya bantuan melalui kecukupan dana hibah yang disalurkan kepada masyarakat melalui program BUMDes UPK Setya untuk mendukung permodalan usaha bagi masyarakat. Kelima, adanya kerjasama dengan pihak ketiga oleh pengelola BUMDes UPK Setya, sehingga BUMDes UPK Setya semakin berkembang.

Sedangkan beberapa Faktor Penghambat yang dihadapi oleh BUMDes UPK Setya adalah sebagai berikut yang pertama, kurangnya sosialisasi kepada masyarakat desa oleh pemerintah desa mengenai keberadaan BUMDes UPK Setya, sehingga masyarakat yang mengetahui BUMDes ini sangatlah terbatas, sehingga anggotanyapun sangat sedikit. Faktor penghambat yang kedua, sedikitnya anggota ini, diperparah dengan minimnya kesadaran masyarakat dalam melakukan pengembalian piutang, sehingga dengan adanya pinjaman macet ini berpengaruh terhadap terbatasnya modal yang dimiliki oleh BUMDes UPK Setya. Faktor yang ketiga adalah meskipun adanya kebijakan mengenai persyaratan kepengurusan BUMDes UPK Setya, namun ternyata dalam pelaksanaannya masih banyak pengurus yang kurang mampu mampu mengelola keuangan BUMDes seperti membuat laporan keuangan.

\section{KESIMPULAN}

Peranan pemerintah desa dalam pengembangan BUMDes Unit Pengelola Keuangan (UPK) Setya adalah 1) Sebagai fasilitator, 2) Pemerintah Desa Tlekung memberikan asistensi (melakukan pendampingan), mentoring dan coaching terhadap Pengurus BUMDes, 3) Pemerintah Desa mendukung setiap kegiatan yang akan dilakukan oleh UPK Setya terutama masalah penganggaran, 4) Memebrikan sosialisasi terhadap masyarakat mengenai keberadaan BUMDes, dan 5) Mendorong BUMDes UPK Setya untuk bekerjasama dengan pihak ketiga Sedangkan faktor-faktor yang mempengaruhi peranan Pemerintah Desa dalam Pengembangan BUMDes Unit Pengelola Keuangan 
JISIP: Jurnal Ilmu Sosial dan IlmuPolitik

ISSN. 2442-6962

Vol. 8 No. 4 (2019)

(UPK) Setya terdiri atas faktor pendukung dan penghambat. Faktor pendukung adalah tersedianya sarana prasana penunjang, adanya kebijakan persyaratan untuk menjadi pengurus, adanya pembinaan manajemen yang dilakukan secara rutin, serta pengawasan baik secara internal maupun eksternal, adanya bantuan melalui dana hibah dan adanya kerjasama dengan pihak ketiga. Sedangkan untuk faktor penghambat yang dihadapi adalah kurangnya sosialisasi kepada masyarakat mengenai keberadaan BUMDes UPK Setya, minimnya kesadaran masyarakat dalam melakukan pengembalian piutang, dan masih minimnya kemampuan pengurus terutama dalam membuat laporan keuangan.

\section{DAFTAR PUSTAKA}

Alam, H. 2009. Ilmu Pengetahuan Sosial (konsep Pemberdayaan masyarakat). Jakarta : Erlangga.

Harahap, dkk. 2007. Kamus Besar Bahasa Indonesia. Bandung: Balai Pustaka.

Larasati, D., \& Adhitama, M. (2018). Monitoring dan Evaluasi Program Dana Desa (DD) sesuai dengan UU Nomor 6 Tahun 2014 tentang Desa (Studi di Desa Landungsari Kecamatan dau

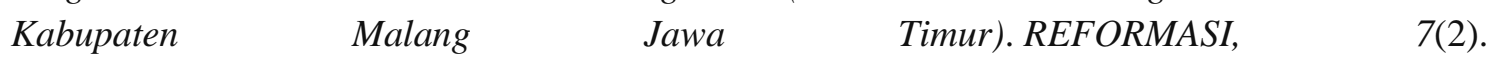
doi:http://dx.doi.org/10.33366/rfr.v7i2.796

Larasati, D., \& Kurrahman, Y. (2019). PERAN PEMERINTAH DESA DALAM MENGELOLA WISATA HUTAN PINUS UNTUK MENINGKATKAN PENDAPATAN ASLI DESA DI DESA BENDOSARI, KECAMATAN PUJON, KABUPATEN MALANG. REFORMASI, 9 (2), 161-167. doi:http://dx.doi.org/10.33366/rfr.v9i2.1509

Moleong, Lexy. 2014. Metodologi Penelitian Kualitatif. Bandung : Remaja Rosdakarya.

Sugiyono. 2014. Metode Penelitian Kuantitatif kualitatif dan R D. Bandung: Alfabeta

Undang-Undang Republik Indonesia Nomor 6 Tahun 2014 tentang Desa. 